\title{
Discards of the commercial boat seine fisheries on Posidonia oceanica beds in the eastern Adriatic Sea
}

\author{
PERICA CETINIĆ, FRANE ŠKELJO and JOSIPA FERRI
}

University of Split, Center of Marine Studies, Livanjska 5/III, 21000 Split, Croatia. E-mail: frane.skeljo@unist.hr

\begin{abstract}
SUMMARY: Scientific observer records were used to estimate the retained and discarded catch composition of the commercial boat seine fisheries over Posidonia oceanica (Linnaeus) Delile meadows in the eastern Adriatic, from November 2008 to December 2009. A total of 91 fish and cephalopod species were recorded in the catches, of which 20 species were always retained, 40 were always discarded and the remaining 31 were selected depending on size (only larger specimens were retained). The most abundant species in the retained catch were Spicara smaris, Atherina hepsetus and Mullus barbatus, while Chromis chromis, Symphodus ocellatus and small specimens of Boops boops dominated the discards. An estimated $43.5 \%$ by number and $28.5 \%$ by weight of the total catch were discarded. Since the minimum landing size (MLS) is regulated for only 4 out of the 15 most important species in this study, and even these regulations are only partially followed, discarding practices were generally market-driven. The retained and discarded amounts of the catch as well as the numbers of retained and discarded species showed a seasonal pattern. The catches recorded during summer/autumn were generally larger than those in winter/spring. High rates of immature specimens were observed for the most important species, which is probably related to the role of Posidonia beds as important nursery grounds.
\end{abstract}

Keywords: boat seine, small-scale fishery, discard, immature fish, Posidonia oceanica beds, Adriatic.

RESUMEN: DesCARTES DE LA PESQUERÍA COMERCIAL DE CERCO QUE OPERA EN LAS PRADERAS DE POSIDONIA OCEANICA AL ESTE DEL MAR ADRIÁTICO. - Registros provenientes de observadores científicos fueron utilizados para estimar la composición de las capturas retenidas y descartadas por parte de la flota comercial cerquera que opera sobre lechos de Posidonia oceanica (Linnaeus) Delile en el Adriático oriental. Desde noviembre de 2008 hasta diciembre de 2009 un total de 91 especies de peces y cefalópodos fueron registradas en las capturas, de las cuales 20 fueron siempre retenidas, 40 fueron siempre descartadas y las restantes 31 fueron seleccionadas de acuerdo al tamaño (sólo los ejemplares mas grandes fueron retenidos). Dentro de la fracción retenida las especies más abundantes fueron: Spicara smaris, Atherina hepsetus y Mullus barbatus, mientras que Chromis chromis, Symphodus ocellatus y los pequeños ejemplares de Boops boops, dominaron los descartes. Se estima que un $43.5 \%$ en números y $28.5 \%$ en peso de las capturas totales fueron descartadas. Dado que la talla minima de desembarque (TMD) está regulada únicamente para 4 de las 15 más importantes especies presentes en este estudio, y aún estas regulaciones son sólo parcialmente cumplidas, las prácticas de descarte fueron determinadas principalmente por las posibilidades de comercialización. Tanto las cantidades como el número de especies retenidas y descartadas mostraron un patrón estacional, con mayores capturas registradas generalmente durante los meses de verano/otoño en comparación a lo obtenido en el periodo invierno/primavera. Altas tasas de ejemplares inmaduros fueron registradas para las más importantes especies, probablemente relacionadas con el papel de las praderas de Posidonia como áreas de criadero.

Palabras clave: barco cerquero, pesquería a pequeña escala, descarte, peces inmaduros, praderas de Posidonia oceanica, Adriático.

\section{INTRODUCTION}

Discards represent a significant proportion of global marine catches and are generally considered to constitute waste or suboptimal use of fishery resources. There is little information on quantifying discards in small-scale and artisanal fisheries, since this is generally not considered to be a priority concern. Although most of these fisheries have been assumed to have a low or negligible discard rate, empirical information is scarce and it is clear that some discarding takes place (Kelleher, 2005). 
Beach seining is a traditional fishing method in Croatia, and its use has been reported as far back as the 11th century (Basioli, 1984). With the introduction of the hydraulic winch, retrieving nets on the beach using manpower was gradually replaced by hauling nets onto the boats with mounted winches, transforming beach seining into a boat seining technique. However, boats are still only several meters away from the shore during hauling, and have thus maintained almost the same fishing areas as during historical beach seining. This technique is still used, and boat seining in the eastern Adriatic strongly resembles beach seining practices worldwide with respect to gear design and the nearshore fishing area.

The boat seine fishery is less common in the eastern Adriatic today, but still of considerable social and economic importance on an artisanal/small scale level (Cetinić et al., 2008). The official number of issued licenses is over 800 , but these figures largely overestimate the actual number of nets in use. According to Cetinić et al. (2008) approximately 150 nets are operated on a regular basis. The most important boat seine fishery in eastern Adriatic waters targets picarel, Spicara smaris, and is practiced in areas inhabited by this species, mainly sandy-muddy bottoms covered with Posidonia oceanica meadows (Bell and Harmelin-Vivien, 1983; Cetinić et al., 1999). According to Bakran-Petricioli et al. (2006), 55\% of the area from 0 to $30 \mathrm{~m}$ of depth along the eastern Adriatic coast is covered with $P$. oceanica. This important habitat plays a multifunctional role within coastal systems, offering substrate for settlement, food availability and shelter, as well as recruitment and nursery areas for both juvenile and adult fish and invertebrates (Bell and Harmelin-Vivien, 1982; Orth et al., 1984; Garcia-Raso, 1990; Proccacini et al., 2003; Nakaoka, 2005).

Compared to the well documented discarding practices in demersal otter trawling and Danish seine fisheries, there is very little information on the composition and level of discards in beach seine or nearshore boat seine fisheries. Most studies have been carried out in South African (Lamberth et al., 1994, 1995; Hutchings and Lamberth, 2002) and Australian waters (Gray et al., 2000, 2001; Gray and Kennelly, 2003; Broadhurst et al., 2008), while studies in the Mediterranean have been conducted by Al-Sayes et al. (1981), Akyol (2003), Faltas (1997), Katsanevakis et al., (2010) and Lefkaditou and Adamiou (1997). Although concerning geographically distant areas, the above mentioned studies characterize beach seining and near-shore boat seining similarly with high discard rates containing juveniles of most of the primary target species. According to Cabral et al. (2003) and Clark et al. (1994), the beach seine fishery produces large amounts of bycatch due to the low fishing gear selectivity. Discard amounts are high because bycatch usually consists of low-value species or species that cannot be marketed due to legal constraints.
In view of European Union regulations, which prohibit the use of towed gears on seagrass beds unless management plans are established for that fishery (Council Regulation 1967/2006, Article 4), and emphasize monitoring and scientific investigations into these activities, a better understanding of the present boat seining practices on $P$. oceanica beds is necessary. Croatian fisheries are currently in the process of harmonization with the EU regulations. Parts of the Council Regulation 1967/2006 regarding the prohibition of fishing activities on seagrass beds have already been adopted in the national legislation, although they are still not enforced. The management plan regarding this fishery has not yet been submitted to the European Council, and a temporary exemption from the above mentioned prohibitions or transitional period will probably be requested. This study aims to describe the discard levels, as well as the composition of the retained catch and discards of the boat seine fishery on Posidonia beds. We also provide data on the proportion of juveniles in the catches of the most important species, which are necessary for evaluating the impact of boat seining on the coastal fish communities.

\section{MATERIALS AND METHODS}

\section{Sampling}

This study was carried out on two commercial fishing boats operating off the eastern Adriatic coast (north-central Mediterranean Sea) from November 2008 to December 2009 (Fig. 1). According to Croatian legislation the boat seine fishery targeting S. smaris is prohibited from sunset to sunrise and from 1 May to 30 September. However, our research was conducted all year-round in order to obtain more comprehensive data on the boat seine fishery and to allow comparisons with similar fishing practices throughout the world in all four seasons. The sampling locations were in traditional fishing grounds covered with Posidonia meadows down to $35 \mathrm{~m}$ deep. The fishing regulations regarding gear design were followed, that is, restrictions on minimum cod-end mesh size $(24 \mathrm{~mm})$ and maximum length of hauling ropes (500 $\mathrm{m}$ at each wing). The boat seines used were approximately $250 \mathrm{~m}$ long (headline length), $20 \mathrm{~m}$ high at the bunt (only the central bunt is used), and $2 \mathrm{~m}$ high at the wing ends.

The fishing technique uses two boats, a larger vessel of 10.0 to $10.5 \mathrm{~m}$ overall length and a smaller boat of 5.5 to $6.0 \mathrm{~m}$. The fishing operation starts when the smaller boat carrying one end of the first hauling rope fastens to the shore (several meters of the rope are used to fasten the boat to any shore object with a ring or small anchor), and the larger boat sets out the required length of the first hauling rope, followed by the net and the second hauling rope in a semicircular shape, ending its operation by fastening the rope to the shore in similar way. At this point the distance between the boats is usually between 300 and $500 \mathrm{~m}$ according to the fishing 


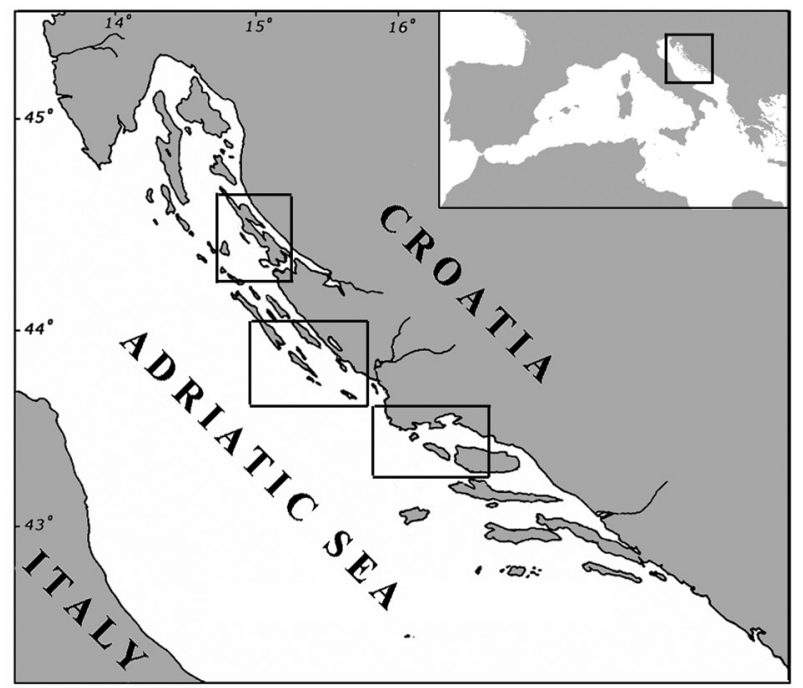

FIG. 1. - Map of the eastern Adriatic Sea (north-central Mediterranean). The boat seine fishing grounds in this study are indicated.

location. After the net is set, each boat hauls one rope with a small hydraulic winch. Boats periodically stop hauling, unfasten from the shore, steer towards one another, fasten to the shore again and resume hauling. In this way the distance between the boats is gradually reduced, drawing the wing ends closer as the net approaches the shore. When the all of the ropes have been hauled in, the boats are side by side and the net is pulled up onto the larger vessel. During the whole hauling operation the boats are less than 4-5 $\mathrm{m}$ from the shore, and the depth at the final net retrieving location usually doesn't exceed 2-3 m.

Data were collected by scientific observers accompanying boat seine crews on four to six fishing trips per season, and during each trip two to four hauls were analyzed (usually five to seven hauls are carried out in one fishing day). A total of 45 hauls were sampled, of which 8 were in spring, 9 in summer, and 14 in autumn and winter alike. The mean haul duration was $50 \mathrm{~min}-$ utes. Since the boat seines used in the sampling had similar characteristics, as well as the fishing operation, duration and area surveyed in each haul, we used one haul as the unit of effort. Depending on the amount of catches, the entire catch was analyzed, or a random sample was taken prior to sorting, and data were scaled accordingly. The sample size varied between 20 and $25 \%$ of the total catch. In both cases, sorting into the retained and discarded components was conducted by the crewmembers and afterwards analyzed by the observers. The retained catch consisted in the target species ( $S$. smaris) and commercially valuable non-target species. Discard refers to the part of the catch thrown overboard, which consisted of undersized or damaged specimens of the commercially valuable non-target species and of non-commercial species. In this study, plants and invertebrates (except cephalopods) were not accounted for discards due to their very low recorded catches.
For each species the total number of individuals and total weight of both the retained and discarded catches were recorded. Whenever possible the length of each specimen was measured, but due to the time constraints we used subsamples of approximately one hundred individuals for the most abundant species in each haul. The total length was recorded for fish species and mantle length for cephalopods. All weights were measured to the nearest $1 \mathrm{~g}$, and lengths to the nearest $1 \mathrm{~cm}$.

In order to estimate the proportion of immature fish in the catches the length frequencies of the 15 most abundant species were compared with the length at first maturity taken from the literature and the minimum landing size (MLS) taken from Croatian legislation. Out of these 15 species, eight are hermaphrodites and in order to assess both sexes, a higher length at first maturity (whether male or female length) was used to separate the immature from the mature specimens.

\section{Data analysis}

Variations in the number of species, number of individuals and biomass per haul (CPUE) of both the retained and discarded catches between seasons were tested using one-way analysis of variance (ANOVA). The statistical assumptions of the analysis of variance were tested using Kolmogorov-Smirnov's test of normality and Levene's test of homogeneity of variances, and when necessary data were log-transformed. The differences in discard rates (discarded proportions of the total catch) between seasons were evaluated by a Kruskal-Wallis test. Relationships between discarded catch per haul and total catch per haul (total catch $=$ retained + discarded catch), and also between discard rates and total catch per haul were tested using the Spearman rank correlation $\left(R_{\mathrm{s}}\right)$. An alpha level of 0.05 was used for all statistical tests.

Numbers of individuals and biomass of all the species recorded in each haul were employed to construct a Bray-Curtis similarity matrix using the PRIMER 5 multivariate statistical package (v. 5.2.9; PRIMER-E Ltd). Species which contributed less than $1 \%$ to the overall number of individuals or total biomass were excluded, and all values were double square root transformed and standardized prior to analysis. The resulting rank similarity matrix was subjected to non-metric multidimensional scaling (MDS) ordination, and subsequent one-way analysis of similarity (ANOSIM) to test whether the species composition of the retained catch and discards differed significantly between seasons. The similarity percentage (SIMPER) analysis was used to determine which species contributed most to any significant dissimilarities between seasons.

\section{RESULTS}

A total of 56303 individuals, representing 91 species (83 bony fish, 1 chondrichthyan and 7 cephalopods) weighing $1120.1 \mathrm{~kg}$ were caught during the present 
TABLE 1. - Mean ( \pm SD) number and weight per haul, discard percentages and frequency of occurrence (FO - number of hauls in which species occurred) for the most abundant species in boat seine catches on Posidonia beds (eastern Adriatic).

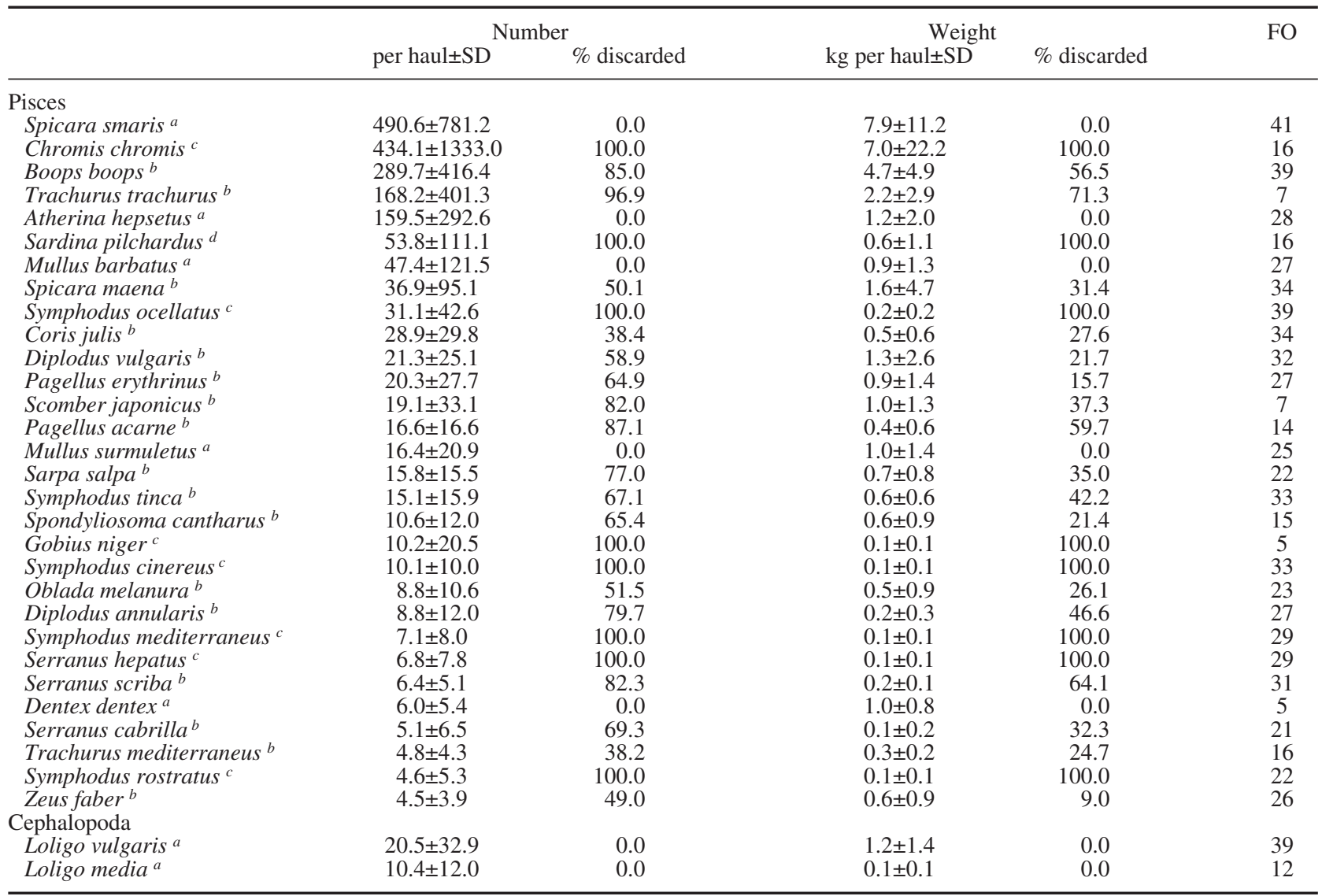

a always retained; ${ }^{\mathrm{b}}$ retained or discarded according to size; ${ }^{\mathrm{c}}$ always discarded (non-commercial); ${ }^{\mathrm{d}}$ discarded due to poor condition

study. The most abundant species were S. smaris, Chromis chromis and Boops boops, as they accounted for $68 \%$ of the total number and $55 \%$ of the total weight, and had mean catches per haul (catch per unit effort) of $7.9,7.0$ and $4.7 \mathrm{~kg}$ respectively. The fourth largest catch per haul was recorded for Trachurus trachurus $(2.2 \mathrm{~kg})$, but this species occurred in only 7 hauls so its abundance in the overall catch was low $(2.1 \%$ of the number and $1.4 \%$ of the total weight). The majority of recorded species were caught in low abundance and 59 species were represented by less than 5 specimens per haul. S. smaris, B. boops, Symphodus ocellatus and Loligo vulgaris were most frequently caught, appearing in 39 to 41 of the 45 analyzed hauls. All cephalopods and 13 fish species were always retained, while 40 fish species were always discarded. Although they are commercial species, Sardina pilchardus and Engraulis encrasicolus were always discarded because of the excessive body damage that occurs during fishing due to the interaction with the net, more robust fish species, invertebrates or debris. Apart from the exclusively retained or discarded species, the remaining 31 fish species were retained or discarded depending on their size (Table 1).

The overall mean catch per haul $( \pm S D)$ in numbers was $1251.2( \pm 1504.1)$ and in weight was $24.9 \mathrm{~kg}$
$( \pm 25.2 \mathrm{~kg})$. Of these amounts, $43.5 \%$ in numbers and $28.5 \%$ in weight were discarded, resulting in $319.2 \mathrm{~kg}$ of discards from a total catch of $1120.1 \mathrm{~kg}$. A greater mean number of individuals and biomass per haul was retained than discarded in all seasons except spring, when the number of discarded specimens slightly predominated (Fig. 2). However, a two-sample t-test only showed significant differences between the weight of the retained and discarded catch in autumn $(\mathrm{t}=3.01, P<0.006)$ and winter $(\mathrm{t}=4.46, P<0.0005)$. The mean number of species discarded was higher than the number of species that was retained in all four seasons, but differences were only significant in autumn $(\mathrm{t}=3.08, P<0.006)$ and winter $(\mathrm{t}=2.25, P<0.035)$.

The mean abundance of the retained catch per haul (CPUE) differed significantly between seasons, and was high during summer and autumn, and comparably low in winter and spring (Fig. 2). The post-hoc Tukey test revealed that there are only significant differences in the number of individuals for summer vs winter, summer vs spring and autumn vs spring. The mean discard abundance per haul showed similar trends to the retained catch, as it was highest in summer and lowest in winter, with only significant differences in the number and biomass caught for winter vs summer and winter vs autumn (Tukey test). The numbers 


\section{- RETAINED $\square$ DISCARDED}
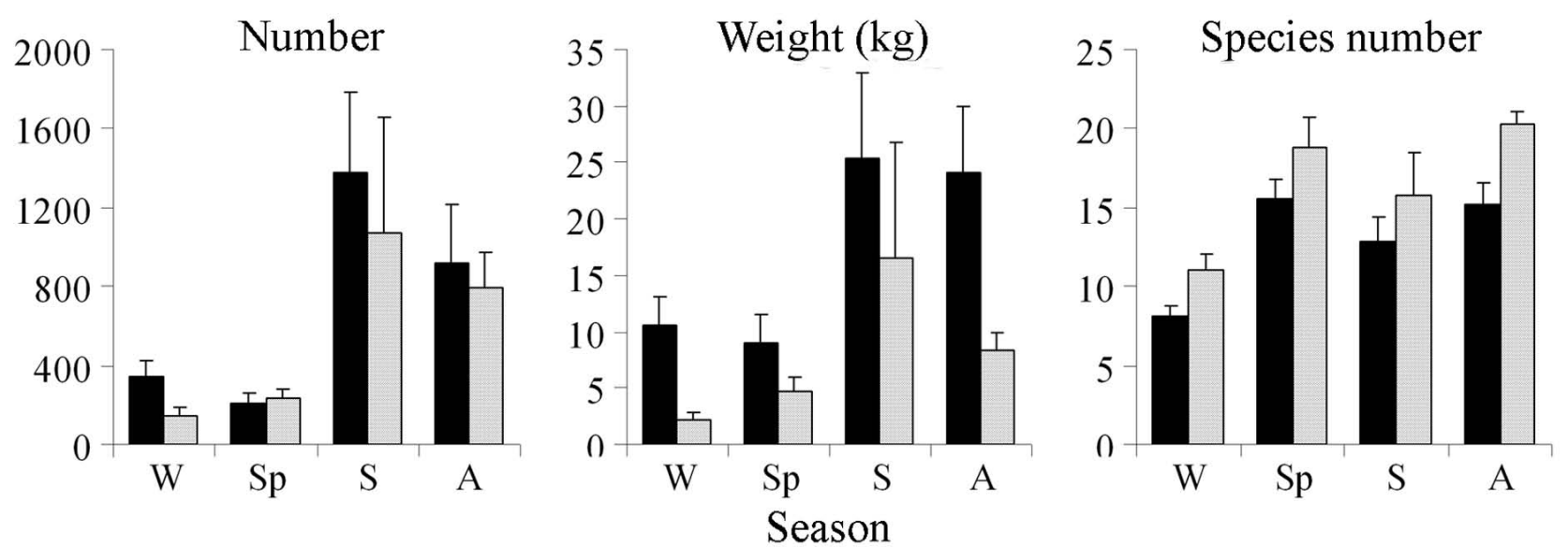

FIG. 2. - Mean values (SE above bars) of retained and discarded catch per haul (CPUE) expressed in number of individuals, total weight and number of species taken in each season (winter - 14 hauls; spring -8 ; summer -9 ; autumn - 14). In all cases the retained and discarded catches were significantly different according to the season $(P<0.01$; for retained weight $P<0.05)$.

of retained and discarded species per haul followed similar seasonal patterns, with significantly lower values recorded during winter (Tukey test; $P<0.05$ when winter was compared with any other season) (Fig. 2). The mean ratio of the retained to discarded number of species was 1:1.4.

The Spearman rank correlation test showed strong statistically significant correlations between the discarded catch per haul and total catch per haul, regarding both the number of individuals $\left(R_{\mathrm{s}}=0.767\right)$ and biomass caught $\left(R_{\mathrm{s}}=0.719\right)$ (Fig. 3a). However, the correlation between the discard rates and total catch per haul was not significant for either the numbers or biomass (Fig. 3b). Differences in discard rates between seasons were not significant in terms of either the numbers $(H=5.3$, $P>0.15)$ or weight $(H=6.0, P>0.11)$.

The multivariate analysis (ANOSIM) based on the number of individuals indicated significant differences among all seasonal comparisons in the retained catch and discarded catch $(P<0.01$; for discards summer vs autumn $P<0.05)$, except for winter vs spring and winter vs summer for the discarded catch, which were not sig- a)

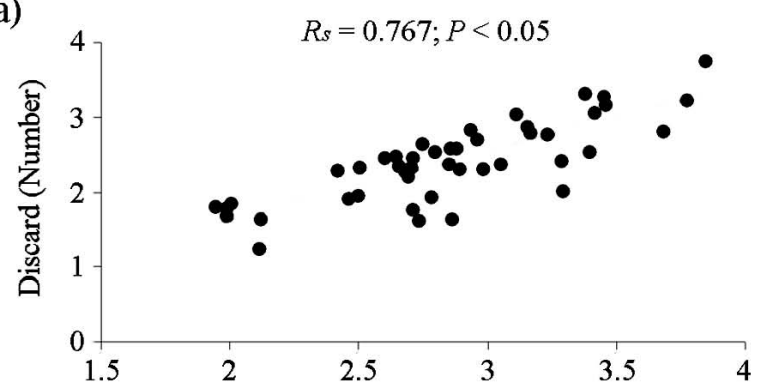

b)

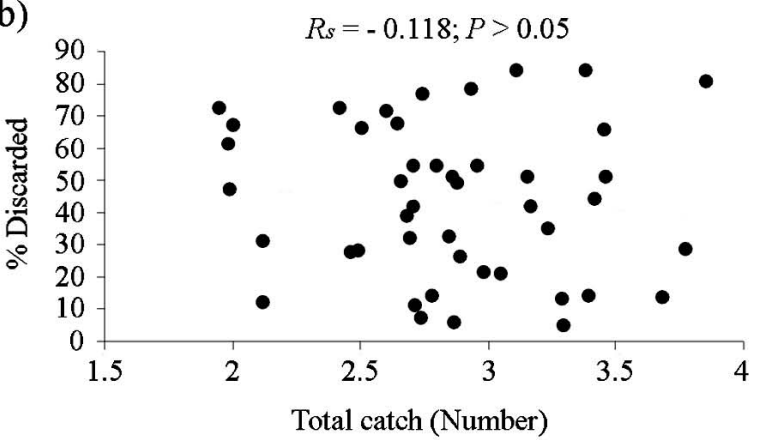

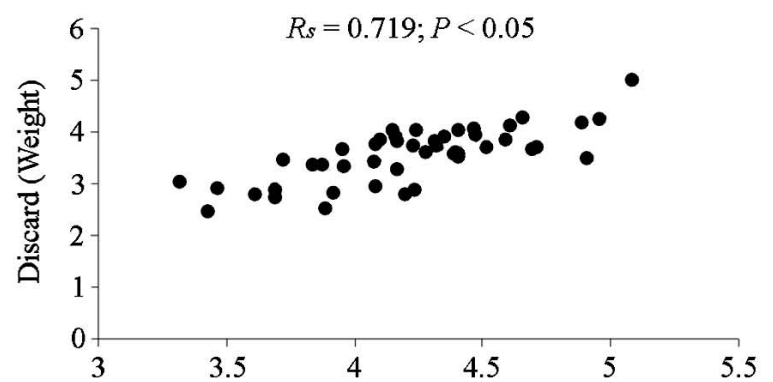

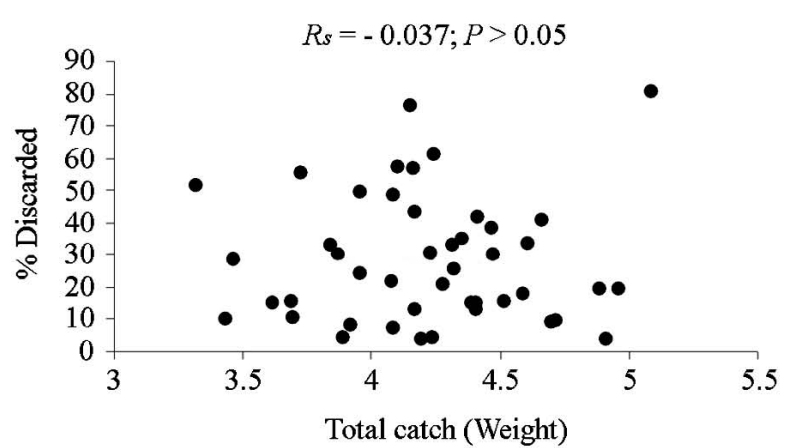

FIG. 3. - (a) Discarded catch per haul (log-transformed) and (b) discard rates vs total catch per haul (log-transformed) in both numbers and weight (weight in $\mathrm{g}$ ). 
a)

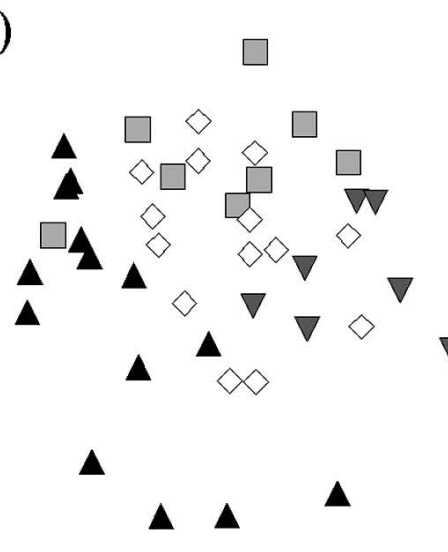

Stress: 0.21

\section{(n)}

$\Delta$ Winter
$\nabla$ Spring
$\square$ Summer
$\diamond$ Autumn b)

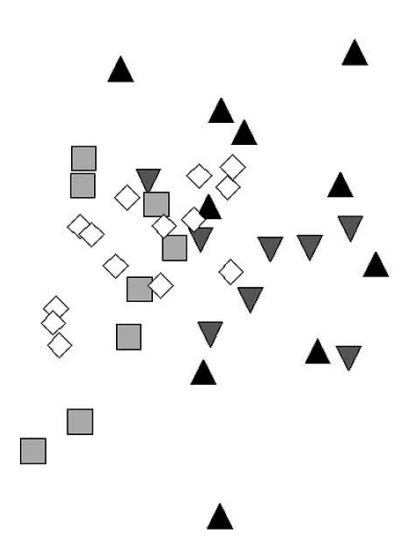

Stress: 0.20

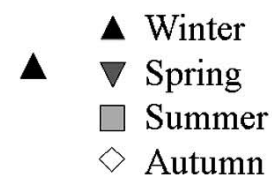

FIG. 4. - MDS ordination showing retained catch composition (a) and discard composition (b) based on numbers of individuals caught in the four different seasons.

nificant. The largest differences were found between the winter and spring samples $(R=0.54, P<0.0002)$, which occupied the left and right sides of the ordinal plot respectively (Fig. 4a). The SIMPER analysis showed that the highest contribution to this dissimilarity came from the species $S$. smaris and Atherina hepsetus (characteristic of the winter period) and Diplodus vulgaris, Pagellus erythrinus and Mullus barbatus (characteristic of the spring period). When the discard structure was assessed, the overall differences between seasons were much less pronounced (Global $R=0.162$, $P<0.0009)$, and the largest differences were between the autumn and spring samples $(R=0.396, P<0.0002)$ (Fig. 4b). The SIMPER analysis showed that the species which contributed most to these differences were small specimens of B. boops and Coris julis (characteristic of the autumn period) and P. erythrinus (characteristic of the spring period).

The size frequency distributions of the fifteen most abundant species are presented in Figure 5, focussing on the retained and discarded part of the catch. C. julis,
Zeus faber, Spicara maena, D. vulgaris, P. erythrinus, Symphodus tinca, Sarpa salpa and B. boops were both retained and discarded with discard rates ranging from 38 to $85 \%$. S. smaris, A. hepsetus, L. vulgaris, M. barbatus and Mullus surmuletus were always retained, while $S$. ocellatus and C. chromis were always discarded (Fig. 6). For species regulated by minimum landing sizes (MLS), all retained $D$. vulgaris and $P$. erythrinus specimens were above MLS, but this wasn't the case for M. barbatus and $M$. surmuletus, which were retained regardless of length (Fig. 5). Although there is no minimum landing size for the other mentioned species, they were usually classified according to length and larger specimens were generally retained. There was no strict length threshold to separate retained from discarded specimens of these species, and considerable overlapping was observed for all but $S$. salpa.The length range with data on length at first maturity and percentage of immature individuals are presented in Table 2. The total catch of S. salpa consisted in immature specimens, and another seven species were represented with more than $50 \%$ of immature individuals.

TABLE 2. - Length range (TL for fish and DML for cephalopods), length at first maturity with references and percentage of immature specimens for the dominant species in boat seine catches on Posidonia beds (eastern Adriatic).

\begin{tabular}{|c|c|c|c|c|}
\hline Species & $\mathrm{N}$ & Length range $(\mathrm{cm})$ & Length at first maturity $(\mathrm{cm})$ & Immature specimens (\%) \\
\hline Spicara smaris & 3267 & $3.8-23.4$ & 12.9 (Stergiou et al., 2004) & 59.8 \\
\hline Boops boops & 1680 & $5.0-23.5$ & 13.0 (Jardas, 1996) & 60.8 \\
\hline Atherina hepsetus & 1276 & $5.5-13.5$ & 9.7 (Froese and Pauly, 2009) & 17.3 \\
\hline Coris julis & 924 & $7.3-21.0$ & 13.0 (Cetinić et al., 1999) & 58.0 \\
\hline Symphodus ocellatus & 882 & $4.6-11.0$ & 5.7 (Quignard and Pras, 1986) & 1.1 \\
\hline Chromis chromis & 701 & $4.5-13.0$ & 8.5 (Dulčić, 1995) & 14.0 \\
\hline Diplodus vulgaris & 667 & $2.2-29.0$ & 19.5 (Cetinić et al., 2002) & 84.6 \\
\hline Spicara maena & 660 & $9.0-23.0$ & 9.1 (Stergiou et al., 1997) $^{1}$ & 1.5 \\
\hline Loligo vulgaris & 548 & $3.0-40.5^{2}$ & 16.0 (Krstulović Šifner, 2000) & 79.6 \\
\hline Symphodus tinca & 496 & $6.3-27.0$ & 10.5 (Quignard and Pras, 1986) & 10.3 \\
\hline Mullus barbatus & 482 & $7.0-25.5$ & 11.5 (Vrgoč, 2000) & 30.3 \\
\hline Mullus surmuletus & 405 & $8.0-26.0$ & 14.0 (Jardas, 1996) & 13.8 \\
\hline Pagellus erythrinus & 391 & $5.6-30.6$ & 12.5 (Vrgoč, 2000) & 57.5 \\
\hline Sarpa salpa & 334 & $7.0-22.2$ & 25.3 (Cetinić et al., 2002) & 100.0 \\
\hline Zeus faber & 118 & $4.0-42.0$ & 31.0 (Vrgoč et al., 2005) & 90.7 \\
\hline
\end{tabular}

19.95 after conversion of FL to TL; ${ }^{2}$ DML 


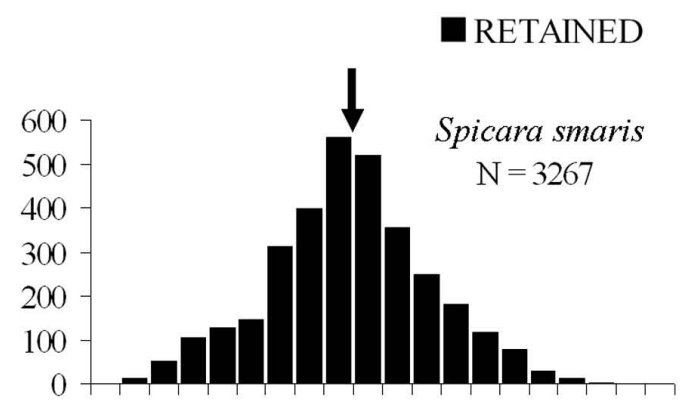

$\square$ DISCARDED

$\begin{array}{llllllllll}4 & 6 & 8 & 10 & 12 & 14 & 16 & 18 & 20 & 22\end{array}$
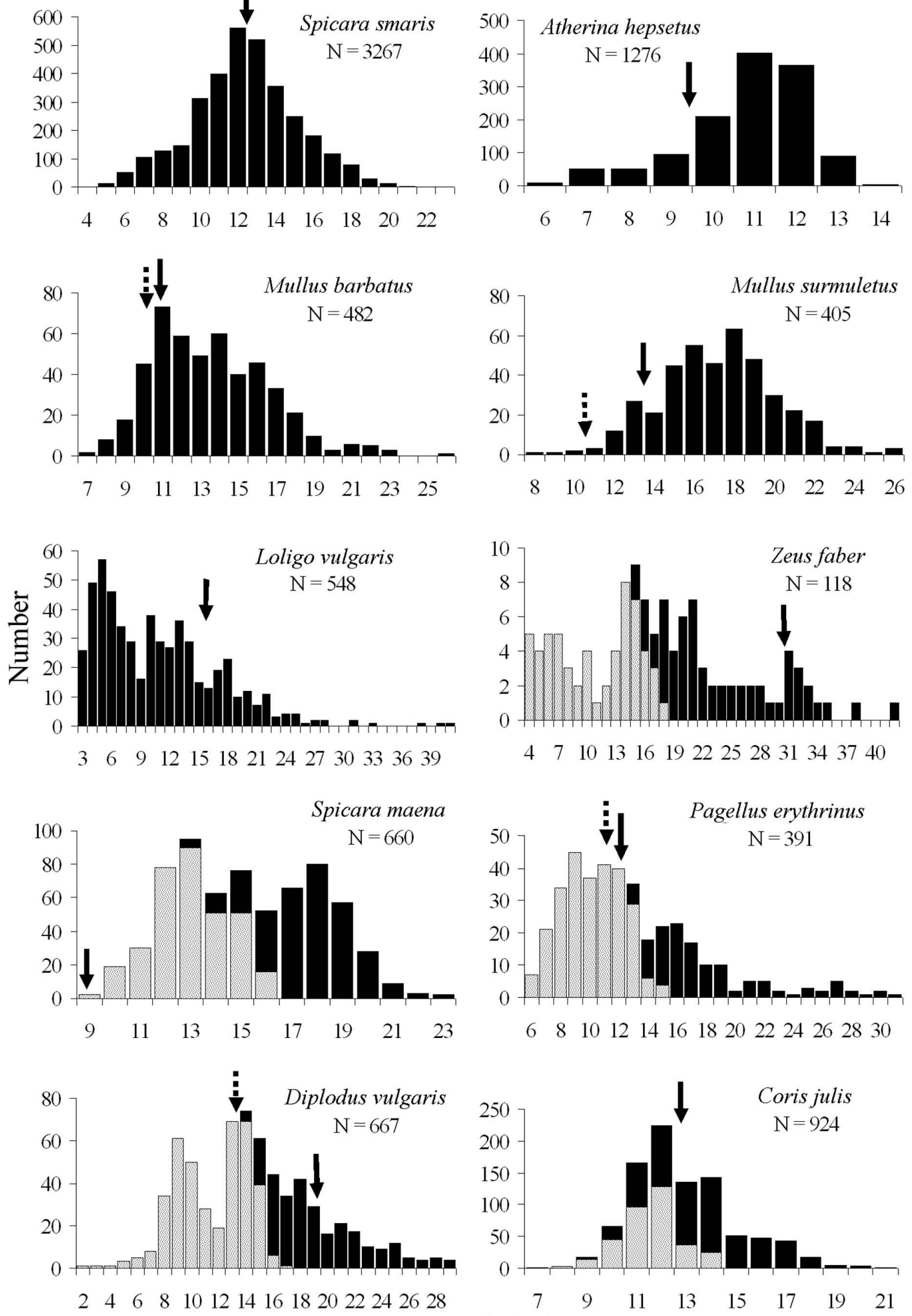

Length $(\mathrm{cm})$

FIG. 5. - Length-frequency distributions of retained and discarded catches of the most important species. Solid arrows denote length at first maturity taken from the literature, dotted arrows indicate minimum landing size (MLS) when regulated. 
- RETAINED $\square$ DISCARDED
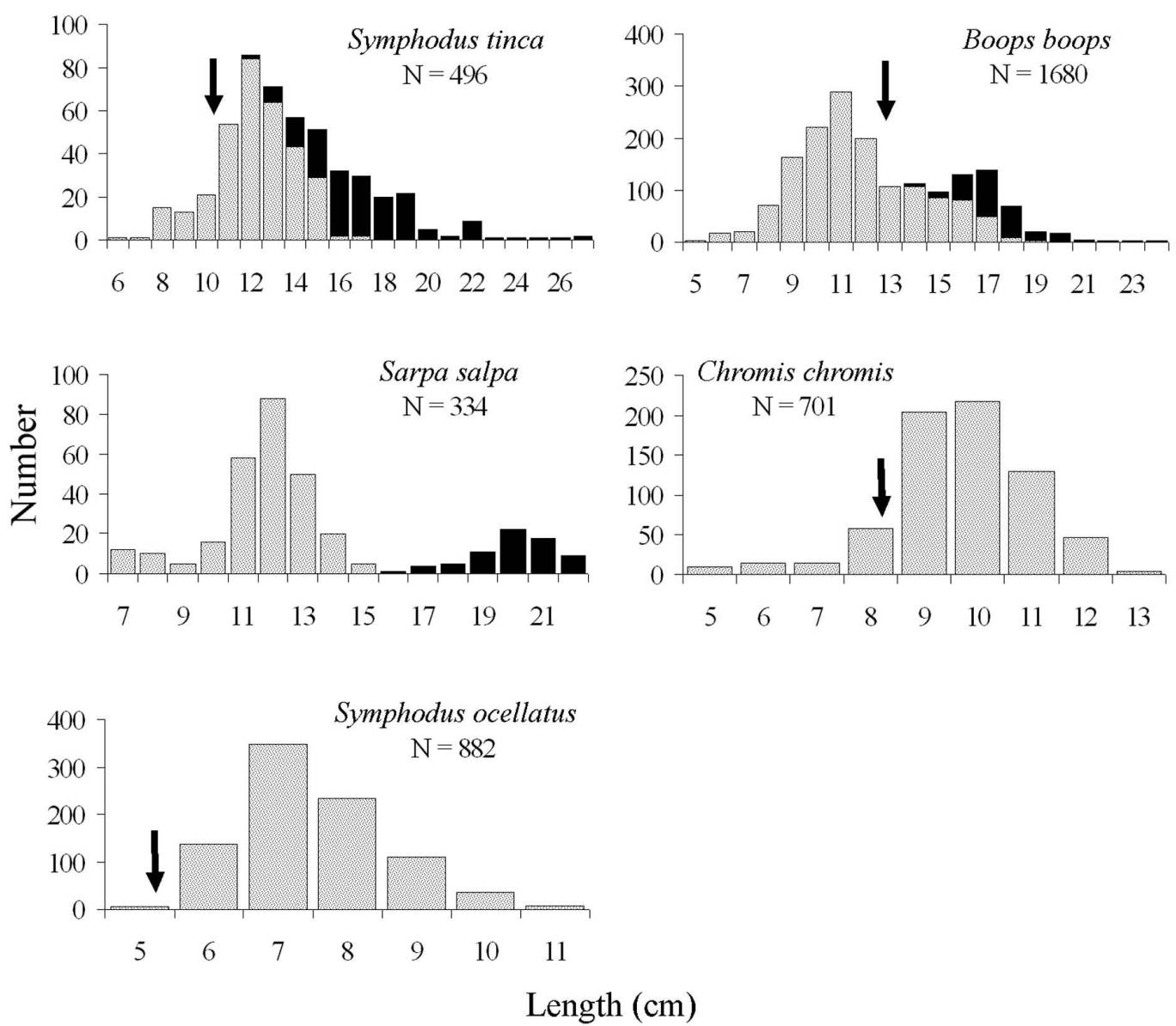

FIG. 5 (Cont.). - Length-frequency distributions of retained and discarded catches of the most important species. Solid arrows denote length at first maturity taken from the literature, dotted arrows indicate minimum landing size (MLS) when regulated.

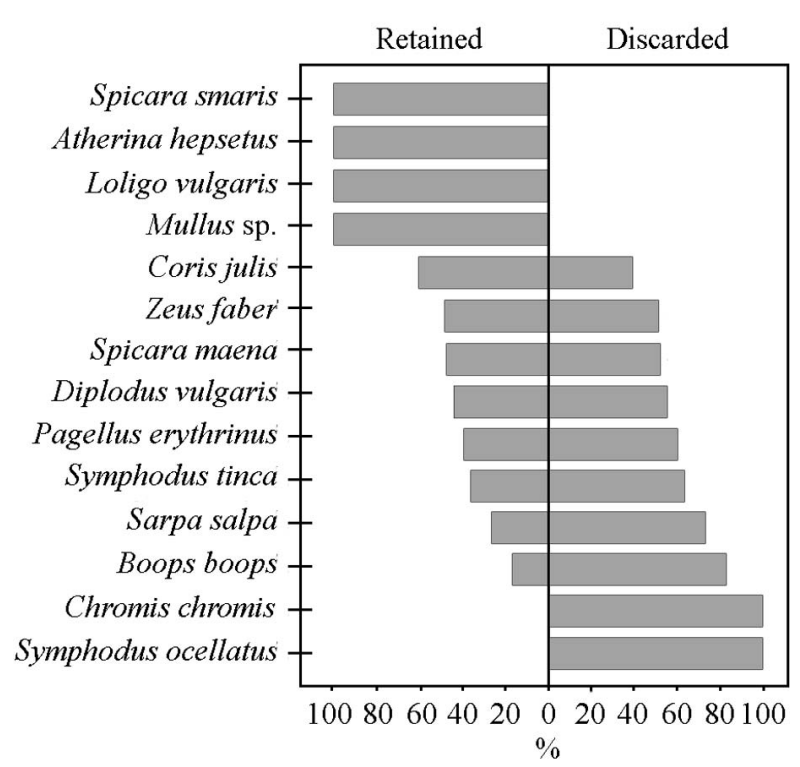

FIG. 6. - Comparison of the retained and discarded portions of the catch for the most important species (estimation based on number of individuals).
With the exception of $M$. barbatus (30\%), the other species were below the $20 \%$ juveniles limit.

The seasonal retained and discarded catch per haul for 12 species is presented in Table 3, and the selected species are shown in Figure 7. S. smaris showed strong seasonal changes, with the largest catches taken during summer and autumn. Similarly, the retained catch of both $A$. hepsetus and S. maena showed significant seasonality, with the largest catches taken in summer. S. ocellatus, S. tinca, M. barbatus and C. chromis had no significant seasonal patterns, although the last two species peaked in summer due to large catches of these species recorded in a single haul. The seasonality of T. trachurus catches couldn't be tested due to the low number of hauls in which this species occurred. $S$. pilchardus wasn't recorded in winter, and its catches were not significantly different between the remaining seasons. When the retained and discarded catch components were compared, larger numbers of individuals were discarded than retained in all seasons for $B$. boops, $P$. erythrinus, $T$. trachurus and $S$. tinca, while $D$. vulgaris and $S$. maena were exceptions from this only during autumn and summer respectively. 
口ETAINED
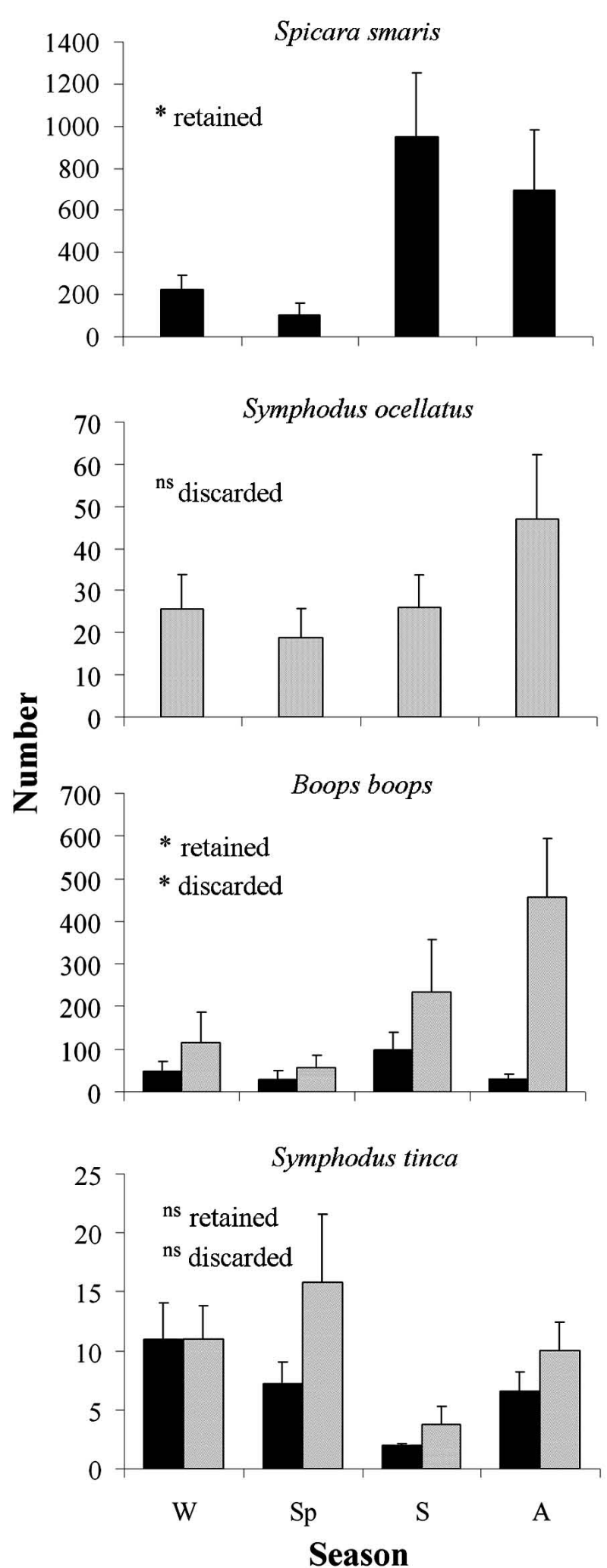

$\square$ DISCARDED
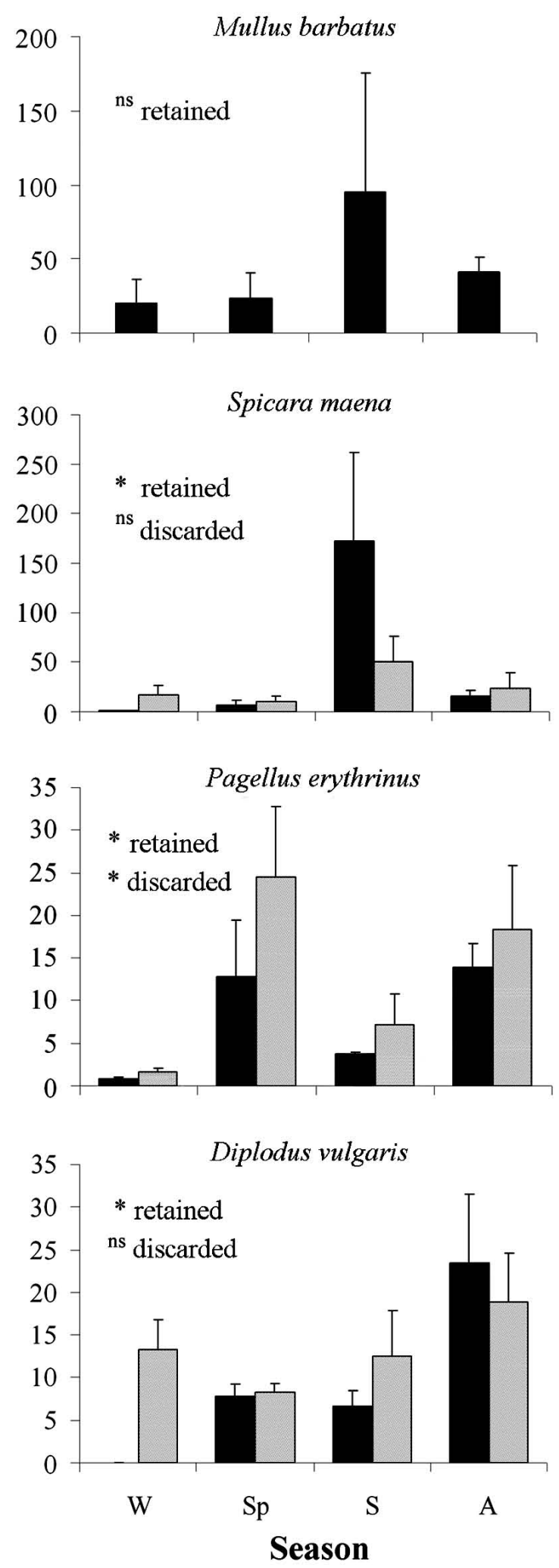

FIG. 7. - Mean values (SE above bars) of retained and discarded catches per haul (CPUE) of individual species in the four different seasons. Statistical significance of differences between seasons is indicated on the corresponding graphs by species: $* P<0.05$; ${ }^{n} P>0.05$ (not significant). 
TABLE 3. - Mean $( \pm \mathrm{SD})$ retained and discarded catch per haul in numbers $(\mathrm{N})$ and weight $(\mathrm{W})$ by season for the most abundant species in boat seine catches on Posidonia beds (eastern Adriatic).

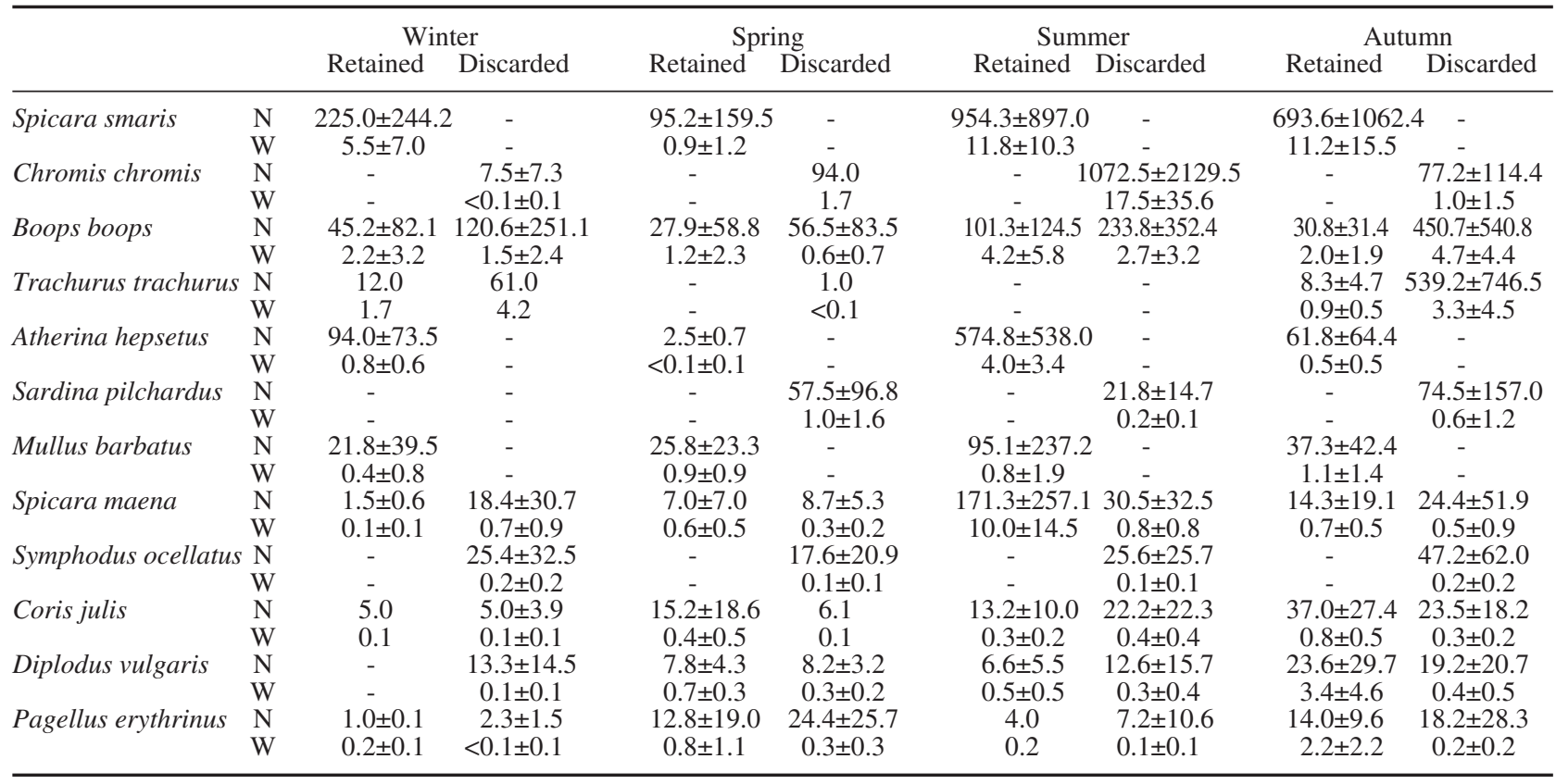

\section{DISCUSSION}

Fish and cephalopod species caught during this research were typical for coastal areas and Posidonia habitats in the Adriatic (Jardas, 1996). The catch composition that was observed showed that the boat seine fishery is both multispecies and non-selective. Although S. smaris is the only target species, specimens of another 51 species were occasionally or exclusively retained for sale. When combined, the catches of these non-target species generally exceed the total catch of $S$. smaris. The average proportion of $S$. smaris in the total catch weight was very low $(28.7 \%)$, and in only one haul proportion of this species exceeded $70 \%$. This percentage is the minimum proportion of a target species in the total catch weight required by national legislation; however, when this regulation is not met fisherman can keep the catch, and are only obliged to change where they fish. Besides $S$. smaris, the composition of the retained catch in our study was also dominated by B. boops, which is very similar to boat seine landings reported for Greece (Aegean and Ionian Sea), where these two species are the most important (Katsanevakis et al., 2010). Many other species are also important to boat seine fisheries in both areas, for example L. vulgaris, S. maena, $P$. erythrinus and M. barbatus. Similarly to previous findings in the central eastern Adriatic (Cetinic et al., 1999, 2008), chondrichthyan species were poorly represented in boat seine catches, with only a single species recorded (Raja miraletus). Chondrichthyans aren't typical of Posidonia meadows along the eastern Adriatic coast (Jardas, 1996), which explains their low abundance in the catches as fishing was confined to this habitat during our research.
In general, catches showed strong seasonality, and most fish were caught in summer and autumn. Only a few species, like $P$. erythrinus and $S$. tinca, were more abundant in spring. The discarded amounts of the catch showed similar seasonal trends as the retained catch, with a high CPUE recorded in summer/autumn and low CPUE during winter/spring. This is expected and easily explained by the high correlation between the discarded and total catch per haul, as large catches lead to large discards and vice versa. Most studies reported seasonal variations with a summer peak in fish abundance (Modde and Ross, 1981; Ross et al., 1987; Lamberth et al., 1994). These variations in the catches reflect the dynamic spatial and temporal nature of fish abundance, which, as Bennett (1989) stated, depends on latitude. Seasonal changes in individual species abundance in boat seine catches during this study can be easily related to their life history, mainly regarding their spawning period. The species which contributed most to this seasonal pattern, S. smaris and B. boops, spawn during the spring and summer months (Jardas, 1996); therefore, their recruitment may explain the high abundance in catches during the summer/autumn period. For a similar catch in weight, the number of S. smaris specimens in summer is much higher than in autumn, due to the presence of low weight recruits. In the case of $B$. boops, recruitment results in large amounts of discards during autumn, since this species is discarded according to size. Many common eastern Adriatic fish species, also caught during this study, spawn during spring and summer. Thus, the time of year in which the sea temperature is increasing coincides with the time when most recruitment takes place. High catches during the summer/autumn period were also recorded for other abundant species (C. chromis, 
S. ocellatus, M. barbatus), but these differences were not statistically significant, possibly due to large inherent variability in catch sizes. The largest catches of $M$. barbatus were taken during the summer when adult specimens move closer to the shore to spawn (Jardas, 1996), and thus spawning occurs in boat seine fishing grounds. The observed decline in abundance of most species during the winter period is probably due to fish moving into deep water to avoid low temperatures.

In the overall survey, the mean discard rate was higher in terms of the number of individuals compared to weight due to the high numbers of low-weight juveniles in the discards. In contrast to the strong seasonality that characterized the numbers and weight discarded per haul, discard rates were not significantly different between seasons. Moreover, no significant correlation was found between discard rates and total catch per haul, which indicates that the discarded proportions are not influenced by either catch amount or season. However, the discard rate was clearly lower in winter and although the difference wasn't significant $(P>0.11)$, further research is needed to clarify this issue.

The discard rates found in our study can be considered as relatively high, but the observed values are smaller than those of the beach seine fishery along the coasts of Portugal (Cabral et al., 2003), Egypt (Faltas, 1997) and South Africa (Clark et al., 1994). Although cod-end mesh size can effect boat seine discard rates (Grey et al., 2000, 2001), with larger mesh resulting in less undersized specimens and consequently less discards, the comparison of our data with those of Clark et al. (1994) suggests that different factors may have an important influence on discard rates in different areas. These authors analyzed beach seines used in South African waters with a very large mesh size compared to those used in our study (44 to $90 \mathrm{~mm}$ vs $24 \mathrm{~mm}$ ), but also found much higher discard rates. This emphasizes the importance of area-specific factors besides gear design on discarding practices, such as local market preferences, minimum legal fish landing sizes, temporal or spatial fishing closures (especially with respect to spawning time and area of the target species), the efficiency of enforcing legal regulations, effects of the tourist season, etc. In our study the main reasons for discarding were: i) lack of commercial value for some of the species caught (non-commercial species), ii) lack of market demand for small specimens of some commercial species, and iii) poor body condition due to damage inflicted during fishing.

As reported for similar fisheries in Australia (Gray et al., 2001) and South Africa (Lamberth et al., 1994, 1995), discards sampled in our study contained juveniles of all commercially important species. For example, the total catch of $S$. salpa consisted entirely of immature specimens, and there were another 7 out of the 14 most important species represented by more than $50 \%$ immature individuals. These high rates are probably because Posidonia beds are important nursery areas. Since sorting of the catch takes place at least 15 minutes after hauling it on deck, most juveniles are returned to the sea already dead. Even when some specimens (usually juveniles of high valued species) were returned immediately, the sea birds following the fishing vessel diminished their chance of survival. This results in a negligible survival rate of discarded fish, and thus high juvenile mortality. A low survival rate was also found for beach seining along the Portuguese coast, where discards are left on the sand for a long time, usually above the intertidal area (Cabral et al., 2003).

The minimum landing size is regulated for only 4 of the 15 most abundant species in the catches, and even these are just partially followed by the fishermen. All retained $D$. vulgaris and $P$. erythrinus specimens were above MLS; however, this wasn't the case for M. barbatus and $M$. surmuletus, which were retained regardless of length, since smaller specimens are also valued and can be sold or used for personal consumption. This is characteristic of the Mediterranean in general, where there is a market for small sized specimens of many species, and the many and dispersed landing points make the MLS difficult to enforce (Kelleher, 2005). Although MLS wasn't followed for two Mullus species, most of the catch consisted of mature individuals. In contrast, these species in the western Mediterranean are intensively exploited by trawls and the bulk of the catches consists in immature individuals recently recruited to the fishery (Martin et al., 1999). Other commercial fish species were retained or discarded mainly according to size, which is closely related to their market value and consumer preferences. These species were not classified as retained or discarded according to a precise length, but rather this depended on the individual judgement of the fisherman; therefore, considerable overlapping was observed for all important species except $S$. salpa.

Although evaluating the physical impact of boat seining on Posidonia beds wasn't the aim of this study, some general observations were made. The most obvious was the absence of leaves or rhizomes inside the cod-end, although they could sometimes be observed in low quantities tangled in the leadline. A single underwater observation didn't reveal noticeable cutting of the leaves or uprooting of the rhizomes (personal observation), but this must be considered as a subjective remark since no scientific examination method was used. This observation is in accordance with Lamberth et al. (1995), who reported that beach seine netting does not have a significant effect on the benthic floor and invertebrate species.

Nowadays, discarding is one of the most important problems of fisheries worldwide. The impact of discarding practices on fish stocks and the marine environment has direct and indirect effects on the population, community, and ecosystem levels that are still largely unknown. At present, the EU Data Collection Framework includes monitoring of discards, but data for the eastern Adriatic are still very scarce. Although we provided information on discard rates in the most common boat seining practice in this area, the 
total amount of discards is impossible to estimate due to the lack of official landing records. Therefore, it is urgent to improve the existing statistical data in order to provide reliable information and improve fisheries management. Besides estimating the discards, our results provide an insight into the impact of boat seining on seagrass beds, which are a valuable marine habitat. This is especially important in the Mediterranean, where Posidonia beds play a fundamental role in the health and productivity of marine ecosystems.

\section{ACKNOWLEDGEMENTS}

The authors wish to thank the Piveta family for all their help and support. This work was funded by the Ministry of Science, Education and Sports of the Republic of Croatia (Project no. 258-0000000-3596).

\section{REFERENCES}

Akyol, O. - 2003. Retained and trash fish catches of beach-seining in the Aegean coast of Turkey. Turk. J. Vet. Anim. Sci., 27: 1111-1117.

Al-Sayes, A.A., M.T. Hashem and I.A. Soliman. - 1981. The beachseine fishery of the Eastern Harbour, Alexandria. Bull. Inst. Oceanogr. Fish. (Cairo), 7: 323-342.

Bakran-Petricioli, T., O. Antonić, D. Bukovec, D. Petricioli, I. Janeković, J. Križan, V. Kušan and S. Dujmović. - 2006. Modelling spatial distribution of the Croatian marine benthic habitats. Ecol. Model., 191: 96-105.

Basioli, J. - 1984. Ribarstvo na Jadranu. Nakladni zavod Znanje, Zagreb.

Bell, J.D. and M.L. Harmelin-Vivien. - 1982. Fish fauna of French Mediterranean Posidonia oceanica seagrass meadows. Téthys, 10: 337-347.

Bell, J.D. and M.L. Harmelin-Vivien. - 1983. Fish fauna of French Mediterranean Posidonia oceanica seagrass meadows. Feeding habits. Téthys, 11: 1-14.

Bennett, B.A. - 1989. The fish community of a moderately exposed beach on the South-western Cape coast of South Africa and an assessment of this habitat as a nursery for juvenile fish. Estuar. Coast. Shelf Sci., 28: 293-305.

Broadhurst, M.K., R.B. Millar, C.P. Brand and S.S. Uhlmann. 2008. Mortality of discards from southeastern Australian beach seines and gillnets. Dis. Aquat. Organ., 80(1): 51-61.

Cabral, H., J. Duque and M.J. Costa. - 2003. Discards of the beachseine fishery in the central coast of Portugal. Fish. Res., 63: 63-71.

Cetinić, P., I. Jardas, J. Dulčić, A. Pallaoro, M. Kraljević and A. Soldo. - 1999. Effects of the "migavica" beach-seine on coastal fish communities. Fol. Univ. Agric. Stetin., 192: 25-35.

Cetinić, P., A. Soldo, J. Dulčić and A. Pallaoro. - 2002. Specific method of fishing for Sparidae species in the eastern Adriatic. Fish. Res., 55: 131-139.

Cetinić, P., I. Jardas, V. Dadić, A. Soldo, J. Ferri, M. Petrić and F. Škeljo. - 2008. Study on importance of traditional fishing zones for coastal trawls, coastal beach-seines and tramata fishing in the eastern Adriatic. University of Split, Split.

Clark, B.M., B.A. Bennett and S.J. Lamberth. - 1994. Assessment of the impact of commercial beach-seine netting on juvenile teleost populations in the surf zone of False Bay, South Africa. S. Afr. J. Mar. Sci., 14: 255-262.

Dulčić, J. - 1995. Dinamika populacije crnelja, Chromis chromis (Linnaeus, 1758) u srednjem Jadranu. Ph.D. thesis, Univ. Zagreb.

Faltas, S.N. - 1997. Analysis of beach-seine catch from Abu Qir Bay (Egypt). Bull. Natl. Inst. Oceanogr. Fish. (Egypt), 23: 69-82.

Froese, R. and D. Pauly. - 2009. FishBase. World Wide Web electronic publication. www.fishbase.org, version (11/2009).

Garcia-Raso, J.E. - 1990. Study of Crustacea Decapoda Taxocoenosis of Posidonia oceanica bed from Southeast of Spain. PSZNI
Mar. Ecol., 11: 309-326.

Gray, C.A., R.B. Larsen and S.J. Kennelly. - 2000. Use of transparent netting to improve size selectivity and reduce bycatch in fish seine nets. Fish. Res., 45: 155-166.

Gray, C.A., S.J. Kennelly, K.E. Hodgson, C.J.T. Ashby and M.L. Beatson. - 2001. Retained and discarded catches from commercial beach-seining in Botany Bay, Australia. Fish. Res., 50: 205-219.

Gray, C.A. and S.J. Kennelly. - 2003. Catch characteristics of the commercial beach-seine fisheries in two Australian barrier estuaries. Fish. Res., 63: 405-422.

Hutchings, K. and S.J. Lamberth. - 2002. Bycatch in the gillnet and beach-seine fisheries in the Western Cape, South Africa, with implications for management. S. Afr. J. Mar. Sci., 24: 227-241.

Jardas, I. - 1996. Jadranska ihtiofauna. Školska knjiga, Zagreb.

Katsanevakis, S., C.D. Maravelias, V. Vassilopoulou and J. Haralabous. - 2010. Boat seines in Greece: Landings profiles and identification of potential métiers. Sci. Mar., 74 (1): 65-76.

Kelleher, K. - 2005. Discards in the world's marine fisheries. An update. FAO Fish. Tech. Pap., 470: 1-131.

Krstulović-Šifner, S. - 2000. Prilog poznavanju biologije i ekologije lignje, Loligo vulgaris (Lamarck, 1798) u Jadranu. Master thesis, Univ. Zagreb.

Lamberth, S.J., B.A. Bennett and B.M. Clark. - 1994. Catch composition of the commercial beach-seine fishery in False Bay, South Africa. S. Afr. J. Mar. Sci., 14: 69-78.

Lamberth, S.J., B.M. Clark and B.A. Bennett. - 1995. Seasonality of beach-seine catches in False Bay, South Africa, and implications for management. S. Afr. J. Mar. Sci., 15: 157-167.

Lefkaditou, E. and A. Adamiou. - 1997. Beach-seine fishery at the Thracian Sea. Preliminary results. Proc. Hell. Symp. Oceanogr. Fish., 2: 21-24.

Martin, P., P. Sartor and M. Garcia-Rodriguez. - 1999. Exploitation pattern of the European hake Merluccius merluccius, red mullet Mullus barbatus and striped red mullet Mullus surmuletus in the western Mediterranean. J. Appl. Ichthyol., 15: 24-28.

Modde, T. and S.T. Ross. - 1981. Seasonality of fishes occupying a surf zone habitat in the northern Gulf of Mexico. Fish. Bull., 78: $911-922$.

Nakaoka, M. - 2005. Plant-animal interactions in seagrass beds: ongoing and future challenges for understanding population and community dynamics. Popul. Ecol., 47: 167-177.

Orth, R.J., K.L. Heck and J. Van Montfrans. - 1984. Faunal communities in seagrass beds: a review of the influence of plant structure and prey characteristics on predator-prey relationships. Estuaries, 7: 339-350.

Proccacini, G., M.C. Buia, M.C. Gambi, M. Perez, G. Pergent, C. Pergent-Martini and J. Romero. - 2003. The seagrass of the western Mediterranean. In: E.P. Green, and F.T. Short (eds.), World Atlas of Seagrasses: Present Status and Future Conservation, pp. 48-58. University of California Press, Berkeley.

Quignard, J.P. and A. Pras. - 1986. Labridae. In: P.J.P. Whitehead, M.L. Bauchot, J.C. Hureau, J. Nielsen and E. Tortonese (eds.), Fishes of the north-eastern Atlantic and the Mediterranean, pp. 919-942. UNESCO, Paris.

Ross, S.T., R.H. McMichael and D.L. Ruple. - 1987. Seasonal and diel variation in the standing crop of fishes and macroinvertebrates from a Gulf of Mexico surf zone. Estuar. Coast. Shelf Sci., 25: 391-412.

Stergiou, K.I., E.D. Christou, D. Georgopoulous, A. Zenetos and C. Souvermezoglou. - 1997. The Hellenic seas: physics, chemistry, biology and fisheries. In: A.D. Ansell, R.N. Gibson and M. Barnes (eds.), Oceanography and marine biology: an annual review, pp. 415-538. UCL Press.

Stergiou, K.I., D.K. Moutopoulos and G. Krassas. - 2004. Body size overlap in industrial and artisanal fisheries for five commercial fish species in the Mediterranean Sea. Sci. Mar., 68: 179-188.

Vrgoč, N. - 2000. Struktura i dinamika pridnenih zajednica riba Jadranskog mora. Ph.D. Thesis, University of Zagreb, Zagreb.

Vrgoč, N., S. Krstulović-Šifner, V. Dadić and S. Jukić-Peladić. 2005. Demographic structure and distribution of John Dory, Zeus faber L. 1758, in the Adriatic Sea. J. Appl. Ichthyol., 22: 205-208.

Scient. ed.: P. Martín.

Received February 19, 2010. Accepted September 20, 2010.

Published online March 10, 2011. 